\title{
低用量アスピリンによる消化管障害に対する酸分泌阻害薬の抑制効果に関する検討
}

\author{
中村浩規, ${ }^{a}$ 横山晴子, ${ }^{a}$ 矢口武廣, ${ }^{a}$ 鈴木優司, ${ }^{b}$ \\ 徳岡健太郎, ${ }^{c}$ 渡邊昌之, ${ }^{b}$ 北川泰久, ${ }^{c}$ 山田安彦 $*, a$
}

\section{Investigation into the Effect of Gastric Secretion Inhibitor for the Prevention of Upper Gastrointestinal Lesions Associated with Low-dose Aspirin}

\author{
Hironori NAKAMURA, ${ }^{a}$ Haruko YOKOYAMA, ${ }^{a}$ Takehiro YAGUCHI, ${ }^{a}$ \\ Yuji SuZUKI, ${ }^{b}$ Kentaro TOKUOKA, ${ }^{c}$ Masayuki WATANABE, ${ }^{b}$ \\ Yasuhisa KITAGAWA, ${ }^{c}$ and Yasuhiko YAMADA*,a \\ aDepartment of Clinical Evaluation of Drug Efficacy, School of Pharmacy, Tokyo University of \\ Pharmacy and Life Sciences, 1432-1 Horinouchi, Hachioji, Tokyo 192-0392, Japan, \\ ${ }^{b}$ Department of Pharmacy, and ${ }^{c}$ Department of Neurology, Tokai University \\ Hachioji Hospital, 1838 Ishikawa-cho, Hachioji, Tokyo 192-0032, Japan
}

(Received July 2, 2010; Accepted November 8, 2010; Published online November 19, 2010)

In this study, we investigated the effect of histamin $\mathrm{H}_{2}$ receptor antagonist $\left(\mathrm{H}_{2} \mathrm{RA}\right)$ or proton pump inhibitor (PPI) for the prevention of upper gastrointestinal lesions associated with low-dose aspirin. We carried out a retrospective study of 2811 patients who had been prescribed low-dose aspirin (Bayaspirin ${ }^{\circledR} 100 \mathrm{mg}$ ) for more than 30 days at Tokai University Hachioji Hospital from 2006 to 2008 . We classified them into three groups: aspirin alone group $(n=1103)$, aspirin with $\mathrm{H}_{2} \mathrm{RA}$ group $(n=844)$ and aspirin with PPI group $(n=864)$. Patients who developed upper gastrointestinal lesions were diagnosed with gastric ulcer, duodenal ulcer, gastritis or duodenitis by gastroscopy. We then compared the incidence of upper gastrointestinal lesions among the groups. The incidence in aspirin alone group, aspirin with $\mathrm{H}_{2} \mathrm{RA}$ group and aspirin with PPI group was $2.54 \%, 1.54 \%$ and $1.04 \%$, respectively; that of aspirin with PPI group being significantly lower $(p<0.05)$. Additively, the odds ratio $(\mathrm{OR})$ of aspirin with $\mathrm{H}_{2} \mathrm{RA}$ group and aspirin with PPI group was 0.60 (95\% confidence interval $[95 \% \mathrm{CI}]: 0.31-1.17)$ and 0.40 (95\% CI: 0.19-0.86) as compared with aspirin alone group, respectively. The upper gastrointestinal lesions were developed within two years in all groups. Our results suggest that the combined administration of low-dose aspirin and PPI is effective for the prevention of upper gastrointestinal lesions associated with low-dose aspirin. Also, the pharmacists should be especially careful for upper gastrointestinal lesions development within two years after administration of low-dose aspirin, regardless of combined whether $\mathrm{H}_{2} \mathrm{RA}$ or PPI.

Key words_- low-dose aspirin; histamine $\mathrm{H}_{2}$ receptor antagonist; proton pump inhibitor; upper gastrointestinal lesion; adverse effect

\section{緒 言}

アスピリンは抗血小板作用を有し，血栓性疾患に おいて血栓形成の再発予防に低用量で用いられてい る.1）抗血小板作用は，アスピリンがシクロオキシ ゲナーゼ（以下，COX)-1 を非可逆的に阻害し，血 小板におけるトロンボキサン $\mathrm{A}_{2}$ の生成を抑制する ことにより発揮される. ${ }^{2)}$ その一方で, COX-1 の非 可逆的阻害は，アスピリンによる消化管障害の発現

$a$ 東京薬科大学薬学部臨床薬効解析学教室, $b$ 東海大学 医学部付属八王子病院薬剂科, c同院神経内科

*e-mail: yamada@ps.toyaku.ac.jp
要因の 1 つして考えられている. ${ }^{3)} \mathrm{COX}-1$ は胃の 粘膜上皮細胞に恒常的に発現していることが知られ ており，アラキドン酸からプロスタグランジン（以 下， PG） $\mathrm{E}_{2}$ が生成される際の酵素として作用して いる. $\mathrm{PGE}_{2}$ は, 胃粘液の分泌促進, 胃粘膜血流量 の増加及び胃酸の分泌抑制に関与する生理活性物質 であるため，アスピリンの投与により COX-1 が阻 害されて胃粘膜上皮細胞の $\mathrm{PGE}_{2}$ 量が減少し，消化 管障害が引き起こされると考えられている. ${ }^{4}$

近年，低用量アスピリンの投与による消化管障害 の予防として, ヒスタミン $\mathrm{H}_{2}$ 受容体拮抗薬 (以下, $\mathrm{H}_{2} \mathrm{RA}$ ）やプロトンポンプ阻害薬（以下，PPI）と 
いつた酸分泌阻害薬の併用が有効であるとの報告が なされている. ${ }^{5)} \mathrm{H}_{2} \mathrm{RA} や P P I$ は，胃酸の分泌を抑 制することによって胃粘膜に対する攻撃因子を減少 させ，アスピリンの投与による胃粘膜防御機構の破 綻によって起こる消化管障害を予防すると考えられ ている. ${ }^{5)}$ また，「EBM に基づく胃潰瘍診療ガイド ライン 2007 年」においても PPI, 高用量 $\mathrm{H}_{2} \mathrm{RA}$ 及 び $\mathrm{PG}$ 製剂を，低用量アスピリンを含む非ステロイ ド性消炎鎮痛薬（以下，NSAIDs）潰瘍の予防に使

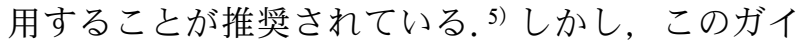
ドラインは日本におけるエビデンスがそしく, 海外 の報告を基に制作されたものである. ${ }^{5)}$ また，日本 人は欧米人と比較して，酸分泌能が低いにもかかわ らず，胃・十二指腸潰瘍の罹患率は高く，わが国に おける低用量アスピリンによる消化管障害に対する 予防法の確立が望まれている，そのような中で，わ が国でも， $\mathrm{H}_{2} \mathrm{RA}$ 又は PPI を併用した患者群で は，それらを併用していない患者群と比較して，胃 の内視鏡所見の評価に使用される Lanza Score（ス コア $0:$ 病変なし, $1:$ 出血性びらん, 2:1-2 個の びらん，3：3-10 個のびらん，4:11 個以上のびら ん，5：潰瘍）が有意に低下したとの報告, ${ }^{6}$ 日本人 健常成人を対象にアスピリン単独又はラベプラゾー ル併用にて服用 1 週間後の胃内 $\mathrm{pH}$ と Modified Lanza Score に関連性があるとの報告7)や, 低用量 アスピリン $(100 \mathrm{mg} / \mathrm{day})$ と PPI（ランソプラゾー ル $15 \mathrm{mg} /$ day，オメプラゾール $10 \mathrm{mg} /$ day） 又は $\mathrm{H}_{2} \mathrm{RA}$ （ファモチジン $10-20 \mathrm{mg} / \mathrm{day}$ ）を併用服用 していた日本人患者において，低用量アスピリン単 独服用群に比べて消化管潰瘍の発現率が有意に低值 を示したとの報告8)など，わが国においてもここ数 年で低用量アスピリンによる消化管障害の予防に関 する報告がある。しかし，これらは頻度又は程度の 報告に留まっており, 低用量アスピリンによる消化 管障害の好発時期などといった発現プロフィール， さらに $\mathrm{H}_{2} \mathrm{RA}$ 又は PPI を併用することによるそれ らの変化について詳細に検討した報告はない.

また，アスピリンによる消化管障害発現時には, アスピリンの抗血小板作用により, 消化管出血を止 血し難く重症化する例も少なくない。さらに，アス ピリンは脳梗塞や心筋梗塞の再発予防のために長期 間服用する必要があり，治療の継続のためにはアス ピリンによる消化管障害を予防することが臨床上,
非常に重要である.

そこで本研究では, 低用量アスピリンによる消化 管障害に対する $\mathrm{H}_{2} \mathrm{RA}$ 又は PPI 併用の抑制効果の プロフィールを明らかにすることで消化管障害発現 の危険性の高い期間を示し，臨床において低用量ア スピリンによる消化管障害を予防するためのデータ を蓄積することを目的に，まずは低用量アスピリン 単独服用群， $\mathrm{H}_{2} \mathrm{RA}$ 併用服用群及び PPI 併用服用 群における消化管障害累積発現頻度を比較検討し た。ついで，低用量アスピリンによる消化管障害累 積発現頻度とアスピリンの投与期間又は累積投与量 との関係を検討した，その上で，各群における消化 管障害累積発現頻度と累積投与量との関係を解析 し，その解析デー夕を基に消化管障害の好発時期に ついて検討した.

\section{方法}

1. 対象 2006 年 1 月 1 日から 2008 年 12 月 31 日までの 3 年間において, 東海大学医学部付属 八王子病院にて低用量アスピリンが 30 日以上処方 された患者を対象に電子カルテを用いて遡及的調査 を行った。ただし， 2006 年 1 月 1 日以前から, 又は 2008 年 12 月 31 日以降も連続して低用量アスピリ ンが処方されている患者については，全服用期間調 査を行った。なお，本研究は東京薬科大学薬学部倫 理委員会及び東海大学医学部付属病院群臨床研究審 查委員会の承認を取得して実施した。他の NSAIDs, 又は副腎皮質ステロイド薬を併用服用していた患 者，ヘリコバクターピロリ陽性又は感染歴のある患 者については除外した。また, 唯一 NSAIDs 潰瘍 に対する適応が承認されている PG 製剤であるミソ プロストールを服用していた患者についても除外し た。消化管障害発現患者は，上部消化管内視鏡検査 （以下，GF）にて胃潰瘍, 十二指腸潰瘍, 胃炎, 十 二指腸炎が確認された患者とし, GF 前日まで対象 薬剂を服用していた患者を薬剂起因による病変の可 能性がある患者として扱った，なお，本研究は遡及 的調査であるため, GF は胃痛などの自覚症状を訴 えた患者に対してのみ施行されていた，また，その 後の再検査において治癒と診断され, アスピリンの 投与が再開された場合においては，消化管障害発見 日までのデー夕のみを解析に用いた，対象薬剤は低 用量アスピリン製剤 (バイアスピリン錠) , $\mathrm{H}_{2} \mathrm{RA}$ 
(ファモチジン， ラフチジン， ラニチジン), PPI (オメプラゾール， ラベプラゾール， ランソプラ ゾール）とした。なお，本研究は遡及的調査である ため，併用薬の選択については無作為に割り付けら れたわけではなく，患者背景を考慮した一般的な医 学的判断基準に基づいて行われた.

2. アスピリン単独服用群, $\mathbf{H}_{2} \mathbf{R A}$ 併用服用群及 び PPI 併用服用群における消化管障害発現頻度及 び発現部位の比較低用量アスピリン製剤を単独 で服用していた患者をアスピリン単独服用群，低用 量アスピリン製剤と $\mathrm{H}_{2} \mathrm{RA}$ 又は PPI を併用服用し ていた患者をそれぞれ $\mathrm{H}_{2} \mathrm{RA}$ 併用服用群，PPI 併 用服用群とし，各群間での消化管障害発現頻度を比 較した。また，消化管障害発現部位に関するデー夕 を GF 施行時の電子カルテより集計し，比較検討し た.

\section{3. 低用量アスピリンによる消化管障害の累積発} 現頻度と服用日数又は累積投与量との関係 アス ピリン単独服用群を対象に検討を行った。まず，消 化管障害の累積発現頻度と服用日数との関係につい て，アスピリンの 1 日投与量毎 $(100 \mathrm{mg} /$ day, 200 $\mathrm{mg} /$ day）に検討した。消化管障害の累積発現頻度 は服用日数 30 日毎にアスピリン単独服用患者数と 消化管障害発現患者数をそれぞれ累積して集計し， アスピリン単独服用患者数に対する消化管障害発現 患者数の割合で算出した.

ついで，消化管障害の累積発現頻度と累積投与量 との関係について検討した．消化管障害の累積発現 頻度は累積投与量として $3 \mathrm{~g}$ （1 日 $100 \mathrm{mg}$ 服用した 場合，30日分に相当する）毎にアスピリン単独服 用患者数と消化管障害発現患者数をそれぞれ累積し て集計し，アスピリン単独服用患者数に対する消化 管障害発現患者数の割合で算出した.

なお，これらの関係の検討においては，アスピリ ン投与中に用量が変更になった患者は除外した。

4. アスピリン単独, $\mathrm{H}_{2} \mathrm{RA}$ 又は PPI 併用による 消化管障害の累積発現頻度と累積投与量の解析

アスピリン単独服用群， $\mathrm{H}_{2} \mathrm{RA}$ 併用服用群， PPI 併用服用群において，消化管障害の累積発現頻度を 累積投与量として $3 \mathrm{~g}$ 毎に算出し，各群における消 化管障害の累積発現頻度と累積投与量との関係につ いて解析した。さらに，各群における消化管障害の 好発時期について検討するために，アスピリン投与
量 $3 \mathrm{~g}$ の区間毎の消化管障害発現頻度（=ある区間 までの消化管障害発現頻度－直前の区間までの消化 管障害発現頻度）を解析デー夕より算出した.

5. 解析 アスピリンの累積投与量と消化管障 害累積発現頻度の関係について，Eq. (1)に示す飽 和型解析モデルを用いて解析を行った。ここで $\mathrm{AE}$ は消化管障害の累積発現頻度（\%)， $\mathrm{AE}_{\max }$ は消化 管障害の最大累積発現頻度（\%)， $\mathrm{D}_{\mathrm{AE} 50}$ は消化管 障害の累積発現頻度が $\mathrm{AE}_{\max }$ の $50 \%$ の時の累積投 与量（g)，D は累積投与量 $(\mathrm{g}), \quad \gamma$ は Hill 係数を示 している.

$$
\mathrm{AE}=\frac{\mathrm{AE}_{\max } \times \mathrm{D}^{\gamma}}{\mathrm{D}_{\mathrm{AE} 50^{\gamma}}+\mathrm{D}^{\gamma}}
$$

解析にはアスピリンの累積投与量と消化管障害累 積発現頻度を累積投与量 $3 \mathrm{~g}$ 毎に算出したデー夕を,

Eq. (1)に非線形最小二乗法を用いて当てはめを行 い，アスピリン単独服用群， $\mathrm{H}_{2} \mathrm{RA}$ 併用服用群及び PPI 併用服用群についてそれぞれ $\mathrm{AE}_{\mathrm{max}}, \mathrm{D}_{\mathrm{AE} 50}$ 及 び $\gamma$ を算出した。 なお，アスピリンによる消化管障 害発現機構はいずれの群においても同じであると考 えられるため, $\gamma$ は同一の值として当てはめを行っ た。解析には MLAB (Civilized Software Inc.) を 用いた。

6. 統計 消化管障害の発現頻度の比較には $\chi^{2}$ 検定及びオッズ比を用いた．有意水準は $p<0.05$ と した。解析には JMP ${ }^{\circledR 8} 8.01$ (SAS Institute Inc.) を 用いた。

\section{結果}

1. アスピリン単独服用群, $\mathbf{H}_{2} \mathbf{R A}$ 併用服用群及 び PPI 併用服用群における消化管障害発現頻度及 び発現部位の比較 低用量アスピリン製剂を服用 していた患者は 2811 名であった，そのうち，アス ピリン単独服用群は 1103 名であり, $\mathrm{H}_{2} \mathrm{RA}$ 併用服 用群は 844 名, PPI 併用服用群は 864 名であった。 アスピリンと $\mathrm{H}_{2} \mathrm{RA}$ 又は PPI の併用率は $60.8 \%$ （1708/2811）であった。 $\mathrm{H}_{2} \mathrm{RA}$ 併用服用群が服用し ていた $\mathrm{H}_{2} \mathrm{RA}$ の割合は，ファモチジンが $83.9 \%$ (708/844)，ラニチジンが $14.0 \%(118 / 844)$ ，ラフ チジンが $2.1 \%$ （18/844）であった。また，PPI 併 用服用群が服用していた PPI の割合は，ランソプ ラゾールが $55.8 \%$ (482/864)， ラベプラゾールが $22.9 \%$ (198/864)，オメプラゾールが $21.3 \%$ （184/ 
864）であった。 なお， $\mathrm{H}_{2} \mathrm{RA}$ 及び PPI ともに各医 療用医薬品添付文書に記載のある常用量範囲内での 投与が行われていた。

対象とした患者群の平均年齢はアスピリン単独服 用群で $67.47 \pm 12.57$ 歳 (mean \pm S.D.)， $\mathrm{H}_{2} \mathrm{RA}$ 併用 服用群で $68.53 \pm 11.80$ 歳, PPI 併用服用群で 68.46 \pm 11.65 歳で各群に有意差はなかった。また，びら ん等の内視鏡的判断による既往があつた患者の割合 は，アスピリン単独服用群では $7.88 \%(140 / 1103)$ であったのに比べ， $\mathrm{H}_{2} \mathrm{RA}$ 併用服用群では $43.60 \%$ (368/844)，PPI 併用服用群では 37.62\%（325/864） と有意に高値を示した。本研究は遡及的調査であ り，患者の治療は保険診療によるものであるため, アスピリン単独服用群と $\mathrm{H}_{2} \mathrm{RA}$ 併用服用群及び PPI 併用服用群の間には既往歴の有無に有意差がみ られたが， $\mathrm{H}_{2} \mathrm{RA}$ 併用服用群と PPI 併用服用群の 間に有意差はなかった。

ついで，アスピリン単独服用群， $\mathrm{H}_{2} \mathrm{RA}$ 併用服用 群及び PPI 併用服用群の消化管障害の発現頻度を Table 1 に示した。アスピリン単独服用群の消化管 障害の発現頻度は $2.54 \%, \mathrm{H}_{2} \mathrm{RA}$ 併用服用群は $1.54 \%$ ，PPI 併用服用群は $1.04 \%$ であり，PPI 併用 服用群はアスピリン単独服用群と比較して消化管障 害の発現頻度が有意に低值を示した $\left(p<0.05, \chi^{2}\right.$ 検定).

アスピリン単独服用群と $\mathrm{H}_{2} \mathrm{RA}$ 併用服用群及び PPI 併用服用群の消化管障害の発現頻度をそれぞれ 比較したオッズ比を Fig. 1 に示した. $\mathrm{H}_{2} \mathrm{RA}$ 併用服 用群のオッズ比は 0.60(95\%信頼区間：0.31-1.17), PPI 併用服用群のオッズ比は 0.40（95\%信頼区間： 0.19-0.86）であり，PPI 併用服用群はアスピリン 単独服用群に比べて消化管障害の発現を有意に抑制 したことが示された。

アスピリン単独服用群, $\mathrm{H}_{2} \mathrm{RA}$ 併用服用群及び PPI 併用服用群の消化管障害の発現部位を Fig. 2 に示した。各群の胃と十二指腸の障害発現部位につ いて比較した結果, 各群に差は認められなかった. また, 詳細な障害発現部位の比較も行ったが, 各群 に差は認められなかった。

\section{2. 低用量アスピリンによる消化管障害の累積発} 現頻度之服用日数又は累積投与量との関係アス ピリン単独服用群において，低用量アスピリンによ る消化管障害の累積発現頻度と服用日数との関係
Table 1. The Incidence of Upper Gastrointestinal Lesions in the Patients Taking Aspirin Alone, Aspirin with PPI and Aspirin with $\mathrm{H}_{2} \mathrm{RA}$

\begin{tabular}{cccc}
\hline \hline $\begin{array}{c}\text { Upper gastrointestinal } \\
\text { lesions }\end{array}$ & $\begin{array}{c}\text { Aspirin } \\
\text { alone }\end{array}$ & $\begin{array}{c}\text { Aspirin } \\
\text { with } \mathrm{H}_{2} \mathrm{RA}\end{array}$ & $\begin{array}{c}\text { Aspirin } \\
\text { with PPI }\end{array}$ \\
\hline Lesion & $28(2.54 \%)$ & $13(1.54 \%)$ & $9(1.04 \%)^{*}$ \\
\hline No lesion & 1075 & 831 & 855 \\
\hline
\end{tabular}

${ }^{*} p<0.05$, compared with aspirin alone, Chi-squared test.

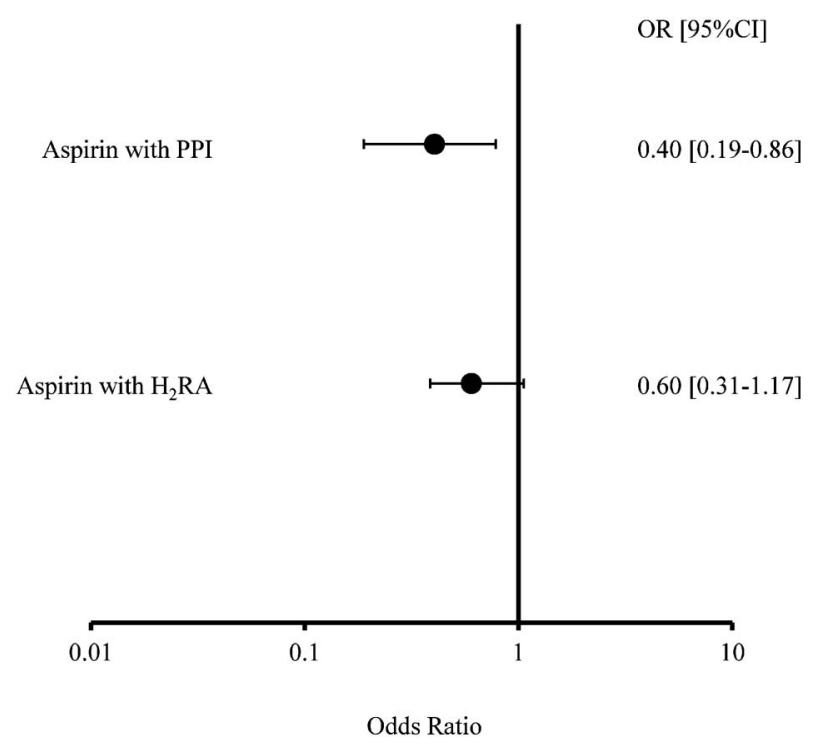

Fig. 1. Odds Ratio of Aspirin with $\mathrm{H}_{2} \mathrm{RA}$ and Aspirin with PPI

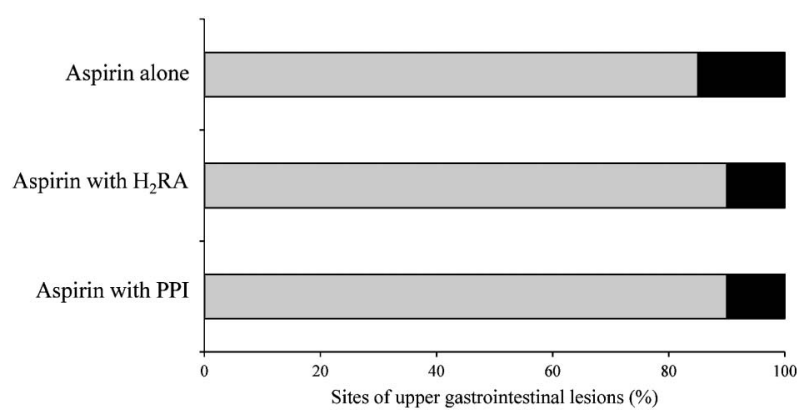

Fig. 2. Sites of Upper Gastrointestinal Lesions in the Patients Taking Aspirin Alone, Aspirin with $\mathrm{H}_{2} \mathrm{RA}$ or Aspirin with PPI

$\square$ : stomach, $\mathbf{\square}:$ duodenum

（A）及び累積投与量との関係（B）を Fig. 3 にそれ ぞれ示した。消化管障害の累積発現頻度と服用日数 との関係においては，投与量により異なるプロフ イールが示された。一方, 消化管障害の累積発現頻 度と累積投与量との関係においては, 両者の間に関 連性がみられた。 
(A)

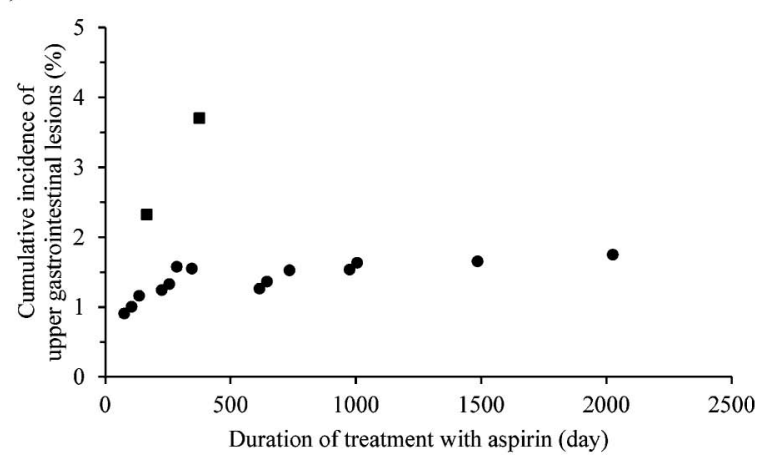

(B)

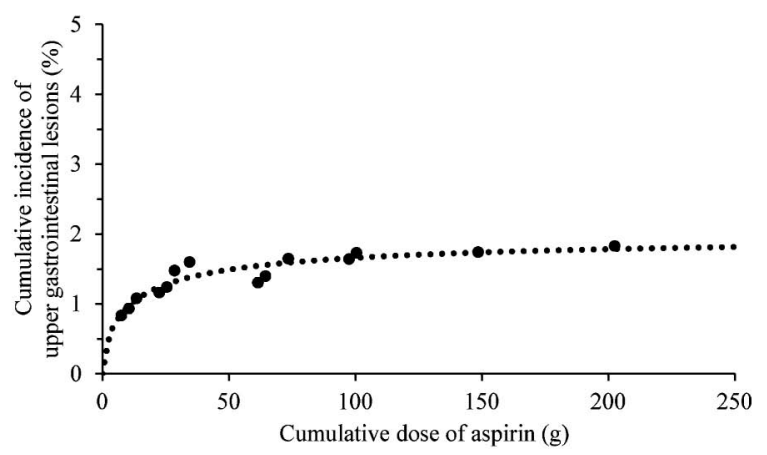

Fig. 3. (A) Relationship between Duration of Treatment with Aspirin and Cumulative Incidence of Upper Gastrointestinal Lesions

○ : $100 \mathrm{mg} /$ day $(n=1028) ; \mathbf{\square}: 200 \mathrm{mg} /$ day $(n=66)$.

(B) Relationship between Cumulative Dose of Aspirin and $\mathrm{Cu}-$ mulative Incidence of Upper Gastrointestinal Lesions

$(n=1094) . \bigcirc$ : Actual value; $\cdots$ : Fitted curve.

3. アスピリン単独， $\mathrm{H}_{2} \mathrm{RA}$ 併用又は PPI 併用に よる消化管障害の累積発現頻度と累積投与量の解析 上記 2 .にて，低用量アスピリンによる消化管障害 の累積発現頻度と累積投与量に関連性がみられたた め，両者の関係を解析した。各群におけるアスピリ ンの累積投与量と消化管障害累積発現頻度の実測値 及びフィッティングカーブを Fig. 4 に示した.い ずれの群においても実測值とフィッティングカーブ は良好な対応を示した。得られた各群の $\mathrm{AE}_{\max }$, $\mathrm{D}_{\mathrm{AE} 50}$ 及び $\gamma$ の值を Table 2 に示した。 その結果, 算出された $\mathrm{AE}_{\max }$ 值はアスピリン単独服用群で $3.23 \%, \mathrm{H}_{2} \mathrm{RA}$ 併用服用群で $2.13 \%$, PPI 併用服用 群で $1.60 \%$ であった.

各群におけるアスピリン投与量 $3 \mathrm{~g}$ の区間毎の消 化管障害発現頻度を Fig. 5 に示した.いずれの群 においても，投与開始から $3 \mathrm{~g}(1$ 日 $100 \mathrm{mg}$ で換算 した場合，約 30 日に相当）までの区間で消化管障 害発現頻度は最大となり，累積投与量約 $60 \mathrm{~g}$ （1 日

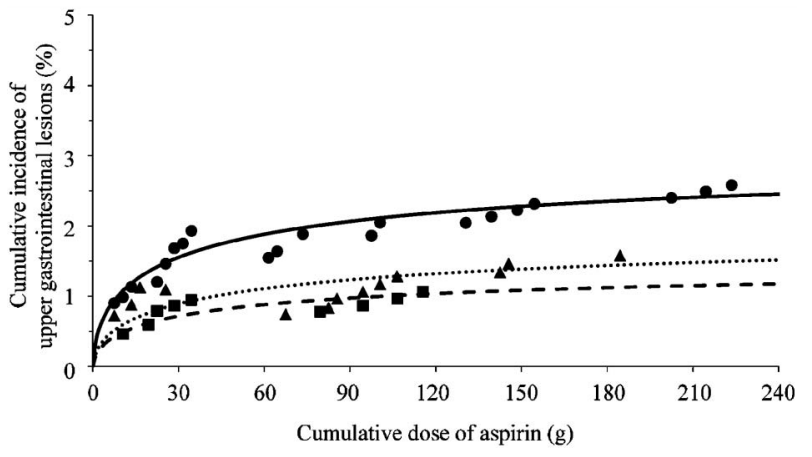

Fig. 4. Relationship between Cumulative Dose of Aspirin and Cumulative Incidence of Upper Gastrointestinal Lesions

- : Actual value (Aspirin alone) $(n=1103),-$ : Fitted curve (Aspirin alone); $\boldsymbol{\Delta}$ : Actual value (Aspirin with $\left.\mathrm{H}_{2} \mathrm{RA}\right)(n=844), \ldots . .$. : Fitted curve (Aspirin with $\mathrm{H}_{2} \mathrm{RA}$ ); $\mathbf{\square}$ : Actual value (Aspirin with PPI) (n =863), - - $:$ Fitted curve (Aspirin with PPI).

Table 2. Estimated Values of $\mathrm{AE}_{\max }, \mathrm{D}_{\mathrm{AE} 50}$ and $\gamma$

\begin{tabular}{cccc}
\hline \hline Parameter & Aspirin alone & $\begin{array}{c}\text { Aspirin with } \\
\mathrm{H}_{2} \mathrm{RA}\end{array}$ & $\begin{array}{c}\text { Aspirin with } \\
\text { PPI }\end{array}$ \\
\hline $\mathrm{AE}_{\max }(\%)$ & $3.23 \pm 0.37$ & $2.13 \pm 0.36$ & $1.60 \pm 0.33$ \\
$\mathrm{D}_{\mathrm{AE} 50}(\mathrm{~g})$ & $34.3 \pm 13.7$ & $52.8 \pm 31.7$ & $43.1 \pm 32.6$ \\
$\gamma$ & & $0.59 \pm 0.10$ & \\
\hline
\end{tabular}

Estimated value \pm S.E.

$100 \mathrm{mg}$ で換算した場合，約 600 日に相当）までの間 に徐々に低下した。さらに，累積投与量約 $90 \mathrm{~g}$ （1 日 $100 \mathrm{mg}$ で換算した場合，約 900 日に相当）以降 では，いずれの群においても各区間における消化管 障害の発現頻度は $0.01 \%$ 未満と低かった。つま り，アスピリンによる消化管障害は，累積投与量と して $60 \mathrm{~g}$ までの間に好発し，90 g 以降ではほとん ど発現しないことが示された.

\section{考察}

低用量アスピリンによる消化管障害の予防として, 2009 年に海外で行われた FAMOUS 試験ではファ モチジン 1 回 $20 \mathrm{mg}$ を 1 日 2 回服用することで低 用量アスピリンによる消化管障害を予防できたとい う結果が報告されている. ${ }^{9}$ また，わが国において も， $\mathrm{H}_{2} \mathrm{RA}$ 及び PPI の投与により, 低用量アスピ リンによる消化管障害を予防できたという報告があ

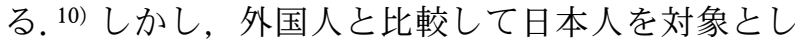
た低用量アスピリンと $\mathrm{H}_{2} \mathrm{RA}$ 又は PPI の併用によ る消化管障害の予防に関する報告は少なく，わが国 において低用量アスピリンによる消化管障害発現に 

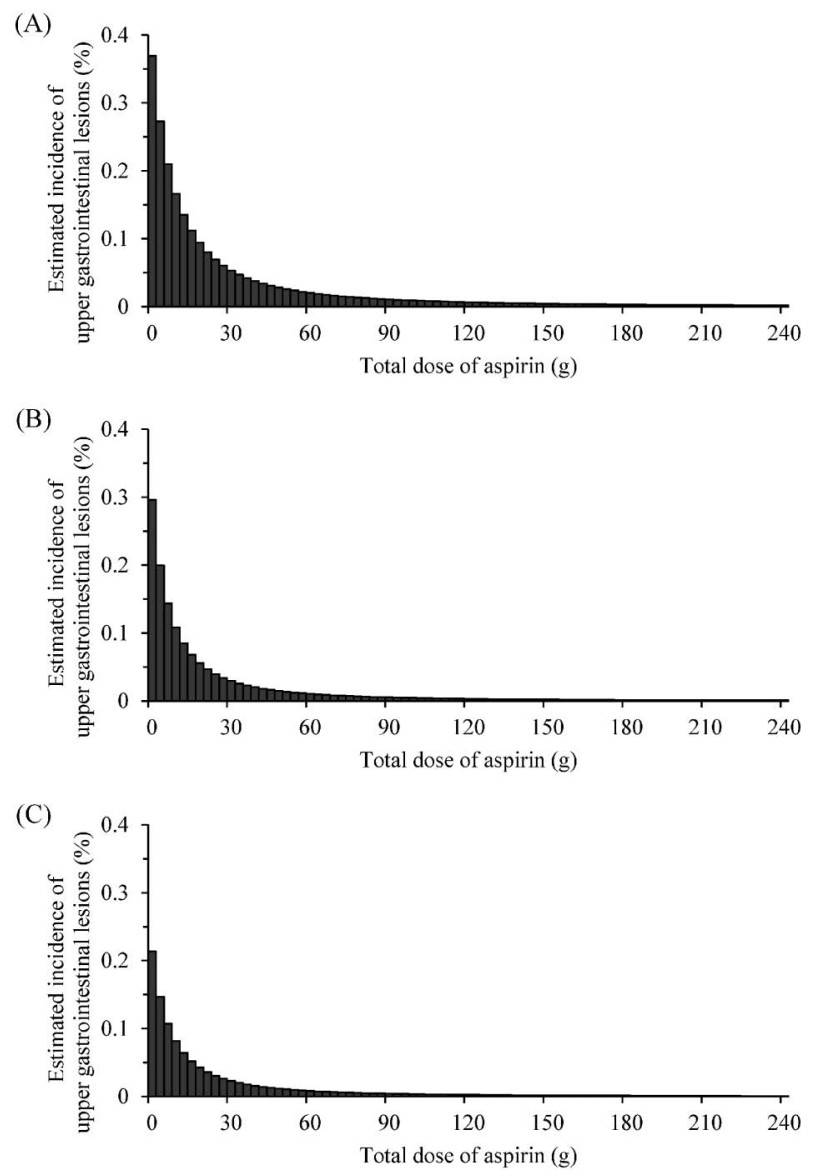

Fig. 5. Estimated Incidence of Upper Gastrointestinal Lesions Every after Administration of $3 \mathrm{~g}$ of Aspirin (A) Aspirin alone, (B) Aspirin with $\mathrm{H}_{2} \mathrm{RA}$, (C) Aspirin with PPI.

対する予防法が確立していないのが現状である.

本調査結果による，アスピリン単独服用群におけ る消化管障害の発現頻度は $2.54 \%$ であり,アスピ リンを 75-325 mg/day の用量で 28 日間以上服用し

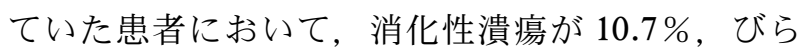
ん性病変が $63.1 \%$ 発現したという海外の既報告 ${ }^{11}$ 及び，バイアスピリン®錠 $100 \mathrm{mg}$ を約 6 年間服用

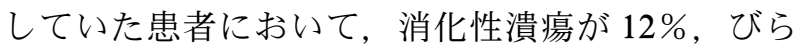
ん性病変が $41 \%$ 発現したという国内の既報告 ${ }^{12)}$ と 比較して低值を示した。これは本調査が遡及的調査 であり，GF の施行が胃痛などの自覚症状を訴えた 患者に限定していたのに対し, 既報告では自覚症状 のない患者についても GF を施行していたことによ るものと考えられた，さらに，低用量アスピリンに よる消化管障害は自覚症状がそしいことが報告 ${ }^{22,13)}$ されているため，全例 GF を施行していた既報告よ りも，消化管障害の発現頻度が低值を示したと考え られた。しかし，アスピリン $283 \mathrm{mg}$ 服用患者にお
いて，自覚症状を訴えた患者のみを対象として内視 鏡検査を施行したところ, 全体の $3.2 \%$ の患者に出 血がみられたとの報告 ${ }^{14)}$ があり, 副作用の重篤度は 異なるものの, 本研究結果の $2.54 \%$ と同等の結果 であった. したがって, 本研究においては自覚症状 のある患者のみを対象に GF を施行し消化管障害発 現頻度を算出したが，これら患者群はアスピリンの 消化管障害に対する $\mathrm{H}_{2} \mathrm{RA}$ 又は PPI 併用による抑 制効果を検討するには適切であったと考えられた。

低用量アスピリンと $\mathrm{H}_{2} \mathrm{RA}$ 又は PPI の併用によ り, 低用量アスピリンによる消化管障害の発現頻度 をそれぞれ 0.60 倍, 0.40 倍に減少できることが示 された．特にPPI 併用時の值は NSAIDsによる胃 潰瘍の予防効果に関するメ夕解析の結果, 5) プラセ ボ併用群との比較で $\mathrm{H}_{2} \mathrm{RA}$ を常用量の倍量で併用 した場合で 0.44 倍, PPI を常用量で併用した場合 で 0.40 倍, 胃潰瘍の発現頻度を減少させたという これまでの報告と同様の結果が得られた。さらに， 胃の内視鏡所見の評価に使用される Lanza Score の 平均值が, アスピリンと $\mathrm{H}_{2} \mathrm{RA}$ を併用していた患 者群で $1.88 \pm 2.25$, PPI を併用していた患者群で $1.00 \pm 1.93$, 及び抗潰瘍薬を併用していない患者群 で $4.74 \pm 0.99$ であり， $\mathrm{H}_{2} \mathrm{RA}$ 併用服用群と PPI 併 用服用群は, 抗潰瘍薬を併用していない患者群と比 較して Lanza Score が有意に低く, 消化管障害の発 現の予防に有効である可能性が示唆されたというわ が国における報告 ${ }^{12)}$ とも一致していた。 一方で, 消 化管障害発現の既往がある患者において低用量アス ピリン $80 \mathrm{mg} / \mathrm{day}$ とファモチジン $40 \mathrm{mg} / \mathrm{day}$ 及び パントプラゾール $20 \mathrm{mg} / \mathrm{day}$ 併用における 48 週間 服用後の消化管障害発現頻度が, ファモチジン併用 群で $20 \%$, パントプラゾール併用群で $0 \%$ であった との報告15)がある. PPIにおいては, 本研究結果及 びこれらの報告からもアスピリン投与時の消化管障 害に対する抑制効果があることが示された。一方,

$\mathrm{H}_{2} \mathrm{RA}$ においては, 本研究結果ではアスピリン単独 服用群と比較して有意差はないものの, 消化管障害 発現頻度を 0.60 倍に減少できることが示された。 また， $\mathrm{H}_{2} \mathrm{RA}$ 併用服用群と PPI 併用服用群におけ る消化管障害の発現頻度の間に有意差はなかった. 既報告においても患者選択などにより結果が異なつ

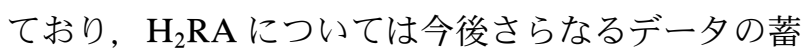
積が必要であることが考えられた. 
本研究の患者背景において，びらん等の内視鏡的 判断による既往があった患者の割合は，アスピリン 単独服用群に比べ $\mathrm{H}_{2} \mathrm{RA}$ 併用服用群及び PPI 併用 服用群で有意に高值を示したのに対し，消化管障害 の発現頻度はアスピリン単独服用群に比べ $\mathrm{H}_{2} \mathrm{RA}$ 併用服用群及び PPI 併用服用群が低值であった。 そのため, $\mathrm{H}_{2} \mathrm{RA}$ 又は PPI などの酸分泌阻害薬の 併用が低用量アスピリンによる消化管障害発現の抑 制に効果的であったと相対的に評価できるものであ る。さらに， $\mathrm{H}_{2} \mathrm{RA}$ 併用服用群と PPI 併用服用群 の患者背景に有意差がなかったため, この 2 群の比 較結果は妥当であると考えられる.

ついで，低用量アスピリンによる消化管障害の累 積発現頻度と服用日数又は累積投与量との関係を検 討した。消化管障害の累積発現頻度と服用日数の関 係においては，アスピリンの投与量により異なるプ ロフィールが示されたため，1 日あたりの投与量毎 の検討が必要であると考えた。しかし，本研究にお いて 3 年間の観察期間にて検討したにもかかわらず, $200 \mathrm{mg} /$ day の用量で投与されていた症例は少な <, 本調査期間中での投与量毎の発現頻度と服用日 数との関係について解析を行うことは困難であっ た。一方，消化管障害の累積発現頻度と累積投与量 との間には関連性がみられた。そこで，飽和型解析 モデルを用いて解析した結果，実測値とフィッティ ングカーブは良好な対応が示され，消化管障害の累 積発現頻度と累積投与量との関係を解析することが できた．国内の既報告13)において，バイアスピリ ン錠 $100 \mathrm{mg}$ を約 6 年間服用していた患者で消化 性潰瘍が $12 \%$ 発現したとの報告があり，消化管障 害の発現頻度は飽和型の様相を示すと考えられるた め, 本解析は妥当と考えられる。 また, 解析によつ て算出された $\mathrm{AE}_{\text {max }}$ は $3.23 \%$ であり，本研究対象 が，自覚症状を訴えた患者のみを対象としているこ とを考慮すると，妥当な值と考えられた.

さらに，解析によって算出された各群の $\mathrm{AE}_{\max }$ 值を比較すると， $\mathrm{H}_{2} \mathrm{RA}$ 併用服用群及び PPI 併用 服用群はアスピリン単独服用群に比べて最大消化管 障害累積発現頻度がそれぞれ約 0.66 倍，約 0.50 倍 に抑えられ，本調査結果の 0.60 倍及び 0.40 倍と同 様の結果が得られた。また， $\mathrm{AE}_{\max }$ 值は各群でそれ ぞれ異なるものの，アスピリン単独服用群， $\mathrm{H}_{2} \mathrm{RA}$ 併用服用群及び PPI 併用服用群におけるアスピリ
ンの累積投与量と消化管障害累積発現頻度の関係は 同様のプロフィールを示し， $\gamma$ を同一の值として解 析したことは妥当であると考えられた。したがつ て，各群ともに消化管障害累積発現頻度はアスピリ ンの累積投与量と関係があることが示唆された。ま た，消化管障害発現頻度と好発時期の関係を解析し た結果，いずれの群においても，低用量アスピリン による消化管障害発現頻度は，投与開始から累積投 与量として $3 \mathrm{~g}$ までの区間で最大となり，累積投与 量約 $60 \mathrm{~g}$ までに徐々に減少し，累積投与量約 $90 \mathrm{~g}$ 以降では消化管障害の発現はほとんどみられないこ とが示された。よって，各群で最大消化管障害発現 頻度は異なるものの，酸分泌阻害薬併用の有無にか かわらず投与開始から約 1-2 年以内に低用量アスピ リンによる消化管障害の大部分が発現することが示 唆された。

ただし， $\mathrm{H}_{2} \mathrm{RA} や P P I$ の併用によっても消化管障 害の発現を完全には防止できないことが示された. その理由としてアスピリンによる COX-1 の非可逆 的阻害作用により $\mathrm{PGE}_{2}$ 量が減少して, 胃粘液分泌 の抑制，胃粘膜血流量の低下，胃酸分泌の六進が起 こるのに対し， $\mathrm{H}_{2} \mathrm{RA}$ 又は PPI は胃酸分泌の抑制 のみにしか作用しないことが考えられた。

以上の結果より，低用量アスピリンと酸分泌阻害 薬を併用することにより，低用量アスピリンによる 消化管障害発現を抑制できることが明らかになっ た。特に，PPIの併用は，低用量アスピリンによる 消化管障害発現を有意に抑制できることが示され た。また，アスピリン単独服用群， $\mathrm{H}_{2} \mathrm{RA}$ 併用服用 群及び PPI 併用服用群ともに低用量アスピリンに よる消化管障害累積発現頻度は，アスピリンの累積 投与量と関係があることが示された。さらに，その 関係はすべての群において傾き（ $\gamma$ ）は同じで，最 大消化管障害累積発現頻度 $\left(\mathrm{AE}_{\max }\right)$ が異なる飽和 型の様相を示した。したがって，アスピリンによる 消化管障害は酸分泌阻害薬の有無にかかわらず，ア スピリン投与開始後早い時期に好発することが示唆 され，1-2 年（300 日-600 日）以内はアスピリン単 独服用群， $\mathrm{H}_{2} \mathrm{RA}$ 併用服用群， PPI 併用服用群のす べてにおいて，消化管障害の発現頻度が高いことか ら，臨床において注意深い観察が必要であることが 示唆された. 


\section{REFERENCES}

1) Hung J., Med. J. Aust., 179, 147-152 (2003).

2) Catella-Lawson F., Reilly M. P., Kapoor S. C., Cucchiara A. J., DeMarco S., Tournier B., Vyas S. N., FitzGerald G. A., N. Engl. J. Med., 345, 1809-1817 (2001).

3) Cryer B., Goldschmiedt M., Redfern J. S., Feldman M., Gastroenterology, 99, 1616-1621 (1990).

4) “Goodman \& Gilman's the Pharmacological Basis of Therapeutics," 10th ed., eds. by Hardman J. G., Limbird L. E., Gilman A. G., The McGraw-Hill Co., New York, 2001.

5) Rostom A., Dube C., Wells G., Tugwell P., Welch V., Jolicoeur E., McGowan J., Cochrane Database Syst. Rev., 4, 1-60 (2002).

6) Nakashima S., Ota S., Arai S., Yoshino K., Inao M., Ishikawa K., Nakayama N., Imai Y., Nagoshi S., Mochida S., World J. Gastroenterol., 15, 727-731 (2009).

7) Nishino N., Sugimoto M., Kodaira C., Yamade M., Shirai N., Ikuma M., Tanaka T., Sugimura H., Hishida A., Furuta T., Dig. Dis. Sci., 55, 1627-1636 (2010).

8) Shiotani A., Sakakibara T., Yamanaka Y.,
Imamura H., Tarumi K., Manabe N., Kamada T., Kusunoki H., Hata J., Haruma K., Gastroenterology, 44, 126-131 (2009).

9) Taha A. S., McCloskey C., Prasad R., Bezlyak V., Lancet, 374, 119-125 (2009).

10) Nakashima S., Arai S., Ishikawa K., Kita H., Yakabi K., Gastroenterology, 45, 273-276 (2007).

11) Yeomans N. D., Lanas A. I., Talley N. J., Thomson A. B., Daneshjoo R., Eriksson B., Appelman-Eszczuk S., Langstrom G., Naesdal J., Serrano P., Singh M., Skelly M. M., Hawkey C. J., Aliment. Pharmacol. Ther., 22, 795-801 (2005).

12) Yajima K., Hodozuka M., Takahashi K., Tomigahara Y., Akashi T., Kawai T., Yamashina A., Kizu J., J. Pharm. Health Care Sci., 35, 649-654 (2009).

13) Abe S., Chiba T., Saito A., Abe H., Hamada S., Prog. Med., 28, 1995-2000 (2008).

14) The Dutch TIA Trial Study Group, N. Engl. Med., 325, 1261-1266 (1991).

15) Ng F.-H., Wong S.-Y. Lam K.-F., Chu W. -M., Chan P., Ling Y.-H., Kng C., Yuen W. -C., Lau Y.-K., Kwan A., Wong B. C. Y., Gastroenterology, 138, 82-88 (2010). 